\title{
Comparison of Early Childhood Education Curriculum Policies between Russia and Indonesia
}

\author{
Irina Muraveva \\ Preschool Director \\ International Preschool of St. Petesburg \\ St. Petesburg, Russia \\ irmuravyova@gmail.com
}

\author{
Evania Yafie \\ Early Childhood Education \\ Universitas Negeri Malang \\ Malang, Indonesia \\ evania.yafie.fip@um.ac.id
}

\begin{abstract}
A country has policies in determining the right of education for people. This is done to achieve the expected goals of a country. Furthermore, the aims of the education process are to develop and build quality people that resemble their nation. One of the determinants of the quality of learning is the curriculum applied. The study used in this paper is a study of literature. The authors make a deep analysis of the curriculum by identifying the curriculum sources directly from Russia and Indonesia. The analysis technique used in this paper is descriptive qualitative. The result of this study indicated that the difference between the education curriculum for children in Russia and Indonesia is certainly obvious according to some adjustments which are based on the needs and characteristics of each country.
\end{abstract}

Keywords- curriculum, early childhood education, curriculum policy

\section{INTRODUCTION}

Education is a basic capital for humans to improve its quality. Through human education, there are various kinds of knowledge, skills and attitude formation within him. Education activities carried out for several important devices as a whole intellectual and emotional in accordance with the surrounding environment and relationship with humans [1]. Therefore the educational process is planned to be planned so that the expected goals. The purpose of the education will be issued well if the curriculum is right. Each country has a different goal. They have different curriculum and policies.

In the education sector curriculum standards in each country are adjusted to the characteristics and objectives of the community that they want to show. The curriculum determines their quality of life. According to Sailor and Alexander, "The curriculum is defined reflecting the volume assessment of the nature of education" [2]. The definitions used also affects on how a curriculum is planned and realized. "That is, the curriculum is a quarter of the plan in the context of a purposeful process. The curriculum is made by several experts in each country to optimize education.

Education in Russia and in Indonesia starts since early childhood. According to J.J. Rousseau, education is defined as a process that gives us debriefing starting from the childhood period whose impact is used in adulthood. Early education will help a child to grow and develop [3]. In addition, we can detect early difficulties or obstacles experienced by children. Child development is also the fastest and most vulnerable is at an early age, so the right stimulus is needed. Provision of the right stimulus will help the child to develop according to his age. But if there are obstacles to early childhood who do not get the right stimulus, then this can be an obstacle when he is an adult.

The characteristics of children in each country are very different. Children who are in Indonesia with Russia are also different. Therefore we need a way to stimulate the right method according to these characteristics.

The results of the scientific research in the field of preschool education and ecperiences surveyed showed the data that all establishments worked of children are based on the basis of a main program for children's education and this scheme was confirmed by the state in upbringing drawn up the detailed information [4]. This is to ensure systematic pedagogical work for every early age child shows positive results. Research conducted by UNICEF in Indonesia showed that one of the causes of stunting in children is poor educational performance [5]. In addition, reducing the early years of school children also causes stunting in children. The last cause is low parental income [6]. Therefore, children benefit the most when the PAUD program is holistic. Holistic is intended to integrate psychosocial preparedness interventions and schools with health and nutrition interventions [7].

Holistic development is very important for the readiness of children in order to enter school life and their ability to participate in learning activities. Early childhood education is very important for children to readily prepare children to face challenges in the next life [8]. Early childhood education is fundamental to a country. Therefore the curriculum on early childhood education in each country is designed according to the objectives. The difference between early childhood education curricula in Russia and Indonesia is certainly based on the history and characteristics of each country. This difference can be used as an input or alternative that may be applied or used as a renewal strategy. Understanding each education plan from a country is very important to measure how far the progress of education is [9]. Therefore, this article will discuss the comparison of early childhood curriculum in Russia and in Indonesia.

\section{METHOD}

The study used is a study of literature. The authors make a deep analysis of the curriculum and its documents that are being applied to each country because the authors come from different countries. Based on the data obtained, the next step conducted was the identification of the curriculum sources directly in their respective countries. The analysis technique used in this paper is descriptive qualitative. 


\section{RESULT AND DISCUSSION}

\section{A. The Curriculum Currently Used}

The preschool curriculum in Russia is called "FSES" and includes education in Russia, including Early Childhood Education. It was implemented on January 1 2014. FSES was designed according to the Constitution of the Russian Federation and the UN Convention on the rights of the child.

Unless of many countries, education and education in Russia, which is guaranteed by the Article 43 of the Constitution of the Russian Federation. "Guarantees shall be provided for general access to and free pre-school, secondary and high school education in municipal educational establishments and enterprises". According to the Education Act 13.01.1996. All levels of education in Russia are free for everyone, including preschool education.

The curriculum used in early childhood education in Indonesia is the 2013 curriculum many people call it K13. This K13 curriculum has been used since October 1, 2014. The curriculum was designed by the Ministry of Education and Culture of the Republic of Indonesia. Early childhood education in Indonesia does not enter into compulsory education. In addition education in Indonesia is not free, but the government provides subsidies in several sectors even though the numbers are not large.

\section{B. Foundation of Curriculum}

Foundation of the Russia curriculum regarding early childhood education consists of eight documents as follows:

1. Federal Law dated 29.12.2000 n 273-FZ (as amended on 07. 05. 2013 with amendments effective from 19.05.2013) "on education in the Russian Federation" on December 29, 2012, No. 273-FZ Adopted by the State Duma on December 21, 2012. Approved by the Federation Council on December 26, 2012). [Chapter 7] [Article 64]

2. Federal Law dated 29.12.2000 n 273-FZ (as amended on 07. 05. 2013 with amendments effective from 19.05.2013) "on education in the Russian Federation" on December 29, 2012, No. 273-FZ Adopted by the State Duma on December 21, 2012. Approved by the Federation Council on December 26, 2012). [Chapter 12] [Article 89]

3. Convention on the Rights of the Child Adopted by General Assembly resolution 44/25 of 20 November 1989. [Article 28]

4. Convention on the Rights of the Child Adopted by General Assembly resolution 44/25 of 20 November 1989. [Article 29]

5. Convention on the Rights of the Child Adopted by General Assembly resolution 44/25 of 20 November 1989. [Article 31]

6. Constitution of the Russian Federation 2016 Relevant wording with Commentaries as of 03. 10. 2016)

7. Order of the Ministry of Education and Science of the Russian Federation (Ministry of Education and Science of the Russian Federation) of October 17, 2013, No. 1155 Moscow "On the approval of the federal state educational standard of pre-school education" Date of signature: 17. 10. 2013. Date of publication: 25. 11. 2013 00: 00. Registered with the Ministry of Justice of the Russian Federation on November 14, 2013. Registration No. 30384)

8. Federal Law dated 29.12.2000 n 273-FZ (as amended on 07. 05. 2013 with amendments effective from 19.05.2013) "on education in the Russian Federation" on December 29, 2012, No. 273-FZ Adopted by the State Duma on December 21, 2012. Approved by the Federation Council on December 26, 2012). [Chapter 1] [Article 2]; Federal Law dated 29.12.2000 n 273-FZ (as amended on 07. 05. 2013 with amendments effective from 19.05.2013) "on education in the Russian Federation" on December 29, 2012, No. 273-FZ Adopted by the State Duma on December 21, 2012. Approved by the Federation Council on December 26, 2012). [Chapter 1] [Article 5].

In comparison, there are nine documents used as the foundation of early childhood education curriculum in Indonesia.

1. Law Number 20 of 2003 concerning the National Education System (State Gazette of the Republic of Indonesia of 2003 Number 78, Supplement Number 4301);

2. Law Number 17 of 2007 concerning the 2005-2025 National Long-Term Development Plan (State Gazette of the Republic of Indonesia of 2007 Number 33, Supplement Number 4700);

3. Government Regulation Number 19 of 2005 concerning National Education Standards as amended by Government Regulation Number 32 of 2013 concerning Amendments to Government Regulation Number 19 of 2005 concerning National Education Standards (State Gazette of the Republic of Indonesia of 2013 Number 71, Supplement Number 5410);

4. Government Regulation Number 17 of 2010 concerning Management and Implementation of Education as amended by Government Regulation Number 66 of 2010 concerning Amendment to Government Regulation Number 17 of 2010 concerning Management and Implementation of Education (State Gazette of the Republic of Indonesia of 2013 Number 112, Supplement Number 5157);

5. Presidential Regulation Number 47 of 2009 concerning the Establishment and Organization of the State Ministries of the Republic of Indonesia as amended several times, the latest by Presidential Regulation No. 13 of 2014;

6. Presidential Regulation Number 5 of 2010 concerning the National Medium Term Development Plan for 2010-2014;

7. Presidential Regulation Number 24 of 2010 concerning Position, Task, Function, Organizational Structure and Work Procedure of the State Ministry of the Republic of Indonesia as amended several 
times, the latest by Presidential Regulation Number 14 of 2014;

8. Presidential Regulation Number 60 of 2013 concerning Holistic-Integrative Early Childhood Development;

9. Presidential Decree of the Republic of Indonesia Number 84 / P of 2009 concerning Formation of United Indonesia Cabinet II as amended several times, the latest by Presidential Decree Number 54 / $\mathrm{P}$ of 2014.

\section{Range and Type of Early Childhood Education}

In Russia, preschool education is considered to be the first stage of general education and considers ages 0 to 7 years old when most of the children go to schools. There are special institutions for early childhood education. The first is a nursery school (yasli) for babies aged six weeks to three years. The second kindergarten (detskie sady) is a school for children aged three to six years.

Usually, both nursery and kindergarten schools are located in the same building. Some of the facilities provided include half-day, all-day and dormitory schools. They vary from year to year to seasonal institutions, most recently in rural areas. Having several regional differences, they mostly have the same programs across the country on the basis of FSIS. However, special facilities are prepared for children who have physical or mental deficiencies. The school will provide these facilities so that children with physical and mental disabilities and other special needs can get school. The school is known as a kindergarten with special functions. Some type of kindergarten schools are:

1. Kindergartens that prioritize one or several child developments, including intellectual, artistic and aesthetic development, and physical;

2. Kindergartens with compensation that prioritize correction of deficiencies or abnormalities in the physical and psychological development of children;

3. Health improvement and supervision of kindergartens prioritizing hygiene, prophylaxis, sanitation, and health improvement measures and procedures;

4. Kindergartens which are combined that is able to to include general development, compensatory, and health improvement groups in various combinations;

5. Child development centers - kindergartens stressing the psychological and physical development, correction and health improvement for all children who attend the school.

In Indonesia, students who attend early childhood education are from 0 to 6 years old. Coaching for children from birth to age 6 (six) years can be done at various early age education institutions. Activities carried out in order to develop children's potential through the provision of educational stimuli. Various stimuli are carried out to help the growth and the development of mental and physical development of the child. This is done so that children are ready to enter primary school. Early childhood education is organized based on age groups and types of services, which include:

1. Early Childhood Education services for children from age 0 to 6 (six) years old consist of Child Care Parks and Similar PAUD Units (SPS), and the equivalent.

2. Early Childhood Education (PAUD) services for ages 2 (two) to 4 (four) years consist of the Play Group (KB) and the like.

3. Early Childhood Education services for ages 4 (four) to 6 ( $\mathrm{six}$ ) years consist of kindergarten (TK) / Raudhatul Athfal (RA) / Bustanul Athfal (BA), and the equivalent.

4. SPS, as referred to in paragraph (1) letter a, includes but is not limited to ECE Post, Taman Posyandu (TP), Christian Child Development PAUD (PAUD PAK), Muslim Childcare Park (TAAM), PAUD Bina Iman Anak (PAUD BIA), Nava Dhamma Sekha.and PAUD Taman Qur'an Al Qur'an (PAUD TPQ).

For children with special needs, generally, all institutions can accept if the child with special needs is in a mild category. Whereas children who are in the moderate and severe category in Indonesia provide special institutions for children with special needs and the curriculum is different.

In general, the age range of children between in Russia and Indonesia has a slight difference. In Russia, early childhood in the age range 0-7 years, while in Indonesia, the age range is 0-6 years. Indonesia limits the range to 6 years because at the age of 7 years the child has entered the primary school category.

\section{Development Program}

The field of development in early childhood education in each country is certainly different. This is because each country has a different purpose. Education with the right goals will produce quality children as future successors of a country [10].

In Russia the development program is in accordance with the law mentioned, the main task of pre-school education institutions is to:

1. Providing development of intelligence, personality, and physical children;

2. Protect the lives of children, including strengthening their health;

3. Make repairs or corrections according to children's needs, especially for children who have abnormalities in their development;

4. Introducing children to a variety of good values for all humanity;

5. Interact with family to ensure and support the development of children fully.

In Indonesia, the curriculum has 6 development areas which are the main objectives. This becomes a standard in accordance with the development of children which is called the Standard Level of Achievement of Child Development. These fields are: 
1. The program of developing religious and moral values as referred to paragraph (a) includes the realization of the learning atmosphere for the development of good behavior originating from religious and moral values and sourced from community life in the context of the play.

2. The physical-motoric development program as referred to in paragraph (1) letter b covers the realization of the development of kinesthetic maturity in the playing context.

3. Cognitive development program as referred to in paragraph (1) letter c covers the realization of the atmosphere for the development of maturity of the thinking process in the playing context.

4. The language development program referred to in paragraph (1) letter $d$ covers the realization of the atmosphere for the development of language maturity in the playing context.

5. The social-emotional development program as referred to in paragraph (1) letter e covers the realization of the atmosphere for the development of attitudes, sensitivity and social skills as well as emotional maturity in the playing context.

6. The art development program as referred to in paragraph (1) letter $f$ includes the realization of the atmosphere for the development of exploration, expression, and appreciation of art in the playing context.

Basically, the field of development in Russia and Indonesia has the same field in developing intelligence, personality, physical, health, moral values. Yet, there are some differences that are not explained in the general Russian social and emotional curriculum, but in the implementation, it has been implemented. Likewise with the curriculum in Indonesia is not explained about the correction of abnormalities, as well as family interaction even though the implementation has been carried out [11].

\section{CONCLUSION}

The curriculum in Russia and Indonesia, in general, is in the same range in Russia 0-7 years and in Indonesia 0-6 years. While in the field of development, it generally has the same development objectives, namely developing cognitive aspects, psychomotor and effective. In Russia, different developments are detecting possible abnormalities in children and parent interaction. While in Indonesia different developments are social and emotional children, and language in early childhood. Institution naming is different. The other different thing is that in Russia education is obtained free of charge while in Indonesia education still pays even though there are some subsidies in some ways.

\section{REFERENCES}

[1] J. Dewey, Democracy and Education. Delhi: Aakar Books, 2004.

[2] J. G. Sailor, and W. M. Alexander, 1974. Planning Curriculum for School. New York: Holt Rine heart and Winstone, Inc.

[3] R. L. Acher, J.J Rousseau His Educational Theories Selected From Emile Julie and Other Writings. New York: Barrons Educational Series. 1964.

[4] M. S. Taratukhina, M. N. Polyakova, T. A. Berezina, N. A. Notkina, R. M. Sheraizina, and M. I. Borovkov. Early childhood care and education in the Russian Federation. Background paper for EFA Global Monitoring Report. 2007, pp. 33.

[5] L.C. Fernald, P. Kariger, M. Hidrobo, and P. J. Gertler, "Socioeconomic gradients in child development in very young children: Evidence from India, Indonesia, Peru, and Senegal," in Proceedings of the National Academy of Sciences, p.201121241. 2012.

[6] S. Grantham-McGregor, Y. B. Cheung, S. Cueto, P. Glewwe, L. Richter, B. Strupp, and International Child Development Steering Group, "Developmental potential in the first 5 years for children in developing countries," in The lancet, vol.369(9555), 2007, pp.60-70.

[7] I. D. Young, "Guidelines for school health programs to promote lifelong healthy eating," in Journal of school health, vol. 67(1), 1997.pp.0.

[8] C. Howes, M. Burchinal, R. Pianta, D. Bryant, D. Early, R. Clifford, and O. Barbarin, "Ready to learn? Children's pre-academic achievement in pre-kindergarten programs," in Early childhood research quarterly, vol. 23(1), 2008, pp.27-50.

[9] G. Psacharopoulos, and M. Woodhall. Education for development. Oxford, UK: Oxford University Press, 1993.

[10] J. Page, Reframing the early childhood curriculum: Educational imperatives for the future. Routledge, 2002.

[11] D. A. Phillips, and P. SJack eds. From neurons to neighborhoods: The science of early childhood development. National Academies Press, 2000 . 